\title{
磁気駆動アークによる鋼材熱処理装置の開発*
}

\author{
秋保 良太 ${ }^{* 1}$, 杉本 尚哉 ${ }^{* 2}$, 武田 紘一 ${ }^{* 3}$ \\ 野口 洋介*4, 三浦 得太郎 ${ }^{*} 4$
}

\section{The Development of a Heat Treatment System Using a Magnetically Driven Arc}

\author{
Ryota AKIHO*1, Masaya SUGIMOTO, Koichi TAKEDA, \\ Yosuke NOGUCHI and Tokutaro MIURA \\ ${ }^{* 1}$ Faculty of Systems Science and Technology, Akita Prefectural University, \\ 84-4 Tsuchiya-Ebinokuchi, Yurihonjo, Akita 015-0055, Japan
}

Transferred arc oscillates in an alternating magnetic field imposed perpendicularly to the arc. The amplitude of oscillatory arc motion can be varied easily by adjusting the magnetic flux density. The heat flux distribution can be controlled by changing the wave form of the magnetic field. Using such magnetically driven arc, the authors developed a novel heat treatment system which consisted of a device for the generation of DC arc, that for the formation of various types of magnetic field, a mechanism for travelling the work piece and water circuit for quenching the heated material. Heat treatments for the steel material of S45C were performed using different wave forms of the magnetic field. The magnetically driven arc was able to produce various patterns of drawing on the steel surface such as a single belt with broad width, two parallel straight lines with different spacing, a series of diamond form and two parallel wavy lines. It was confirmed that Vickers hardness increased more than three times after the heat treatment.

Key Words : Iron and Steel, Heat Treatments, Transferred Arc, Magnetic Field, Electromagnetic Force

\section{1. 緒言}

輸送機械等に使用される構造用の鋼材には，高勒性を有して衝撃吸収力が高く，さらに高強度で而摩耗性に優 れた特性が求められる。一方, 機械の高機能化が進み, 部品は複雑多様になっており, 高い加工性も求められて いる．しかし，加工性と高強度性は両立させることが困難であるため，加工性の良い鋼材を用いて加工し，その 後，熱処理を施して強度を高める方法が用いられる．鋼材の性質は化学組成のみで決まるわけではなく，熱処理 により大きく変化する．現在，鋼材の熱処理には，ガスバーナ一や高周波誘導加熱が用いられているが，部分的 な加熱が困難であり，形状の歪みや材質の劣化が起こりやすい. さらに，鋼材の全体を熱処理により高強度化し てしまうと，勒性が損なわれ破壊しやすく安全性が失われる。そこで，高勒性部分を残し，一部を高強度化した 材料とすることが望ましい.

本研究では，熱源として局所的に高エネルギーを得られるアークを用い，次章で述べる磁気駆動技術を活用す る鋼材熱処理装置の開発を行っている．磁気駆動技術では，アークの電磁流体的性質を利用し，アークに外部磁 界を作用させることによりアークの形状や電極点位置を制御できる．作用磁界を交流とすると複数の箇所を同時 に加熱することができる．金属表面の狙った箇所に局所的な熱処理を行えば，高勒性と高強度を併せ持つ材料の 製造が可能になる.

\footnotetext{
* 原稿受付 2013 年 4 月 2 日

${ }^{* 1}$ 学生員, 秋田県立大学大学院 システム科学技術研究科（テ015-0055 秋田県由利本荘市土屋字海老ノロ 84-4)

${ }^{* 2}$ 正員, 秋田県立大学大学院 システム科学技術研究科

*3 秋田県立大学

${ }^{* 4}$ (株) 三栄機械（＝０15-0051＼cjkstart秋田県由利本荘市川口字家妻 146-3）

E-mail: M14A001@akita-pu.ac.jp
} 
磁気駆動アークの原理について次章で簡単に述べ，3 章では磁気駆動アーク技術を利用した鋼材熱処理装置に ついて説明する.さらに 4 章以降ではこの装置を用いた鋼材の熱処理実験と結果について述べる.

\section{2. 磁気駆動アークの原理}

アークは自己ピンチ効果により熱流が狭い範囲に集中するため, 広範囲の加熱は不得意とされている. アーク によるエネルギー供給面積を広げるための研究(1) (6) は過去にいくつかなされてきた. 磁気駆動アークによる鋼材 熱処理装置は，アークの電磁流体としての特性を活かし，アークに磁界を作用させてアーク形状を制御寸る技術 を応用している. 図 1 に本研究で用いるアークの磁気駆動法の原理的概略図を示す．陰極であるプラズマトーチ と陽極の間に発生する移行型アークに対して，アーク発生空間に設置された磁界発生コイルによりアークに直交 する外部磁界を印加することで,アーク電流と外部磁界の間で発生するローレンツカによってアークが変形する. 開発している鋼材熱処理装置では, 磁界発生コイルに対して交流の励磁電流を供給し, 交番の外部磁界を発生さ せることで，往復運動するアークを得ることができる．例えば，正弦波に近い励磁電流を供給すると，アークの 往復運動の広がりを持つ扇形の広幅な熱源が得られることになる．磁気駆動技術ではアークに作用させる外部磁 界の変動波形を調節することで広幅熱源内の熱流分布を制御することができる. 図 2 は矩形波励磁電流を供給し た外部磁界を印加した場合のアーク形状を示している.この場合, アークの往復運動した熱源幅の両端に熱流が 集中し，異なる二箇所が同時に加熱される.

以上述べた特徵をまとめると磁気駆動アークには以下の特徵がある.

（1） アークを用いることにより高いエネルギー密度が得られる.

（2）アアク電流の制御で出力を迅速かつ正確に制御できる.

（3）励磁電流の変化により熱源の幅を容易に制御できる.

（4）＼cjkstart励磁電流の波形を変化させることにより熱分布の制御が可能である.

これらの特徴により，高速に複雑なパターンの熱処理が可能になると考えられる.

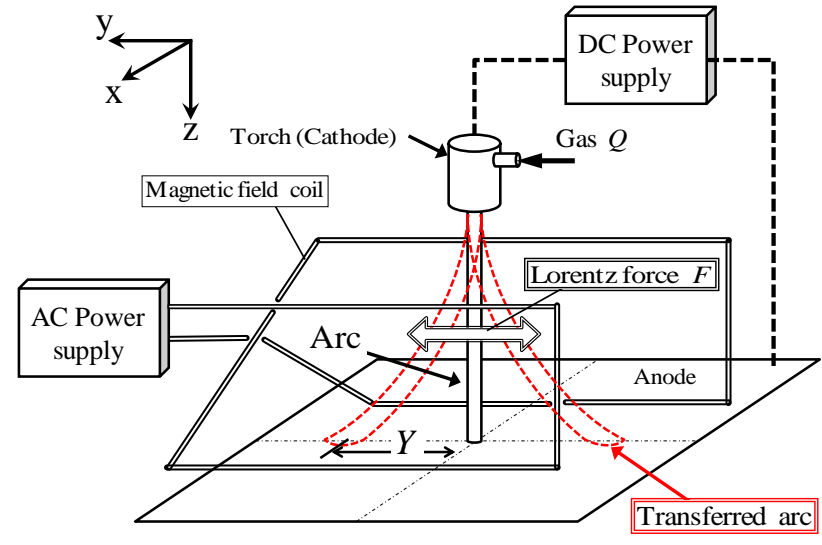

Fig. 1 Schematic illustration of a magnetically driven arc.

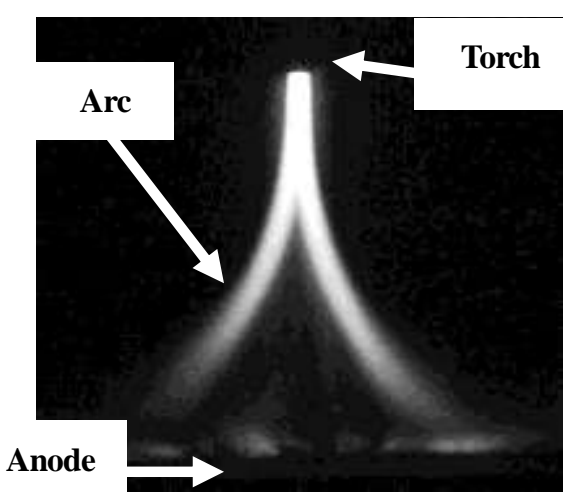

Fig. 2 Arc driven by an AC magnetic field with rectangular wave form.

先行研究より，アークに作用する磁界が空間的に均一であるとすると，アークの形状は円弧状になり，往復運 動する陽極点の振幅 $Y[\mathrm{~m}]$ は次式の関係で表されることが知られている(7).

$$
\begin{aligned}
& Y=R-\sqrt{R^{2}-L^{2}} \\
& R=\frac{U Q}{I_{a} B}
\end{aligned}
$$


ここで， $R[\mathrm{~m}]$ は外部磁界により曲げられたアークの曲率半径であり， $L[\mathrm{~m}]$ は電極間距離である. $R[\mathrm{~m}]$ の值は 式 (2) で表される. $U[\mathrm{~m} / \mathrm{s}]$ はプラズマガス速度, $Q[\mathrm{~kg} / \mathrm{s}]$ はプラズマガス流量, $I_{a}[\mathrm{~A}]$ はアーク電流值, $B[\mathrm{~T}]$ は 磁束密度である. 式 (1) より, $R[\mathrm{~m}]$ が $L[\mathrm{~m}]$ よりも小さくなると, 式 (1) 右辺第 2 項の平方根内が虚数とな り，安定なアークが存在しないことが分かる. すなわち， $Y[\mathrm{~m}]$ は理論的に $L[\mathrm{~m}]$ より大きくなることはできな い.アークが安定に存在するためには磁束密度がある值以下でなければならないことは実験から確かめられてい る.

\section{3. 磁気駆動アークによる鋼材熱処理装置}

\section{$3 \cdot 1$ 装置の概要}

磁気駆動アークによる鋼材熱処理装置構成の概略を図 3 に示す.

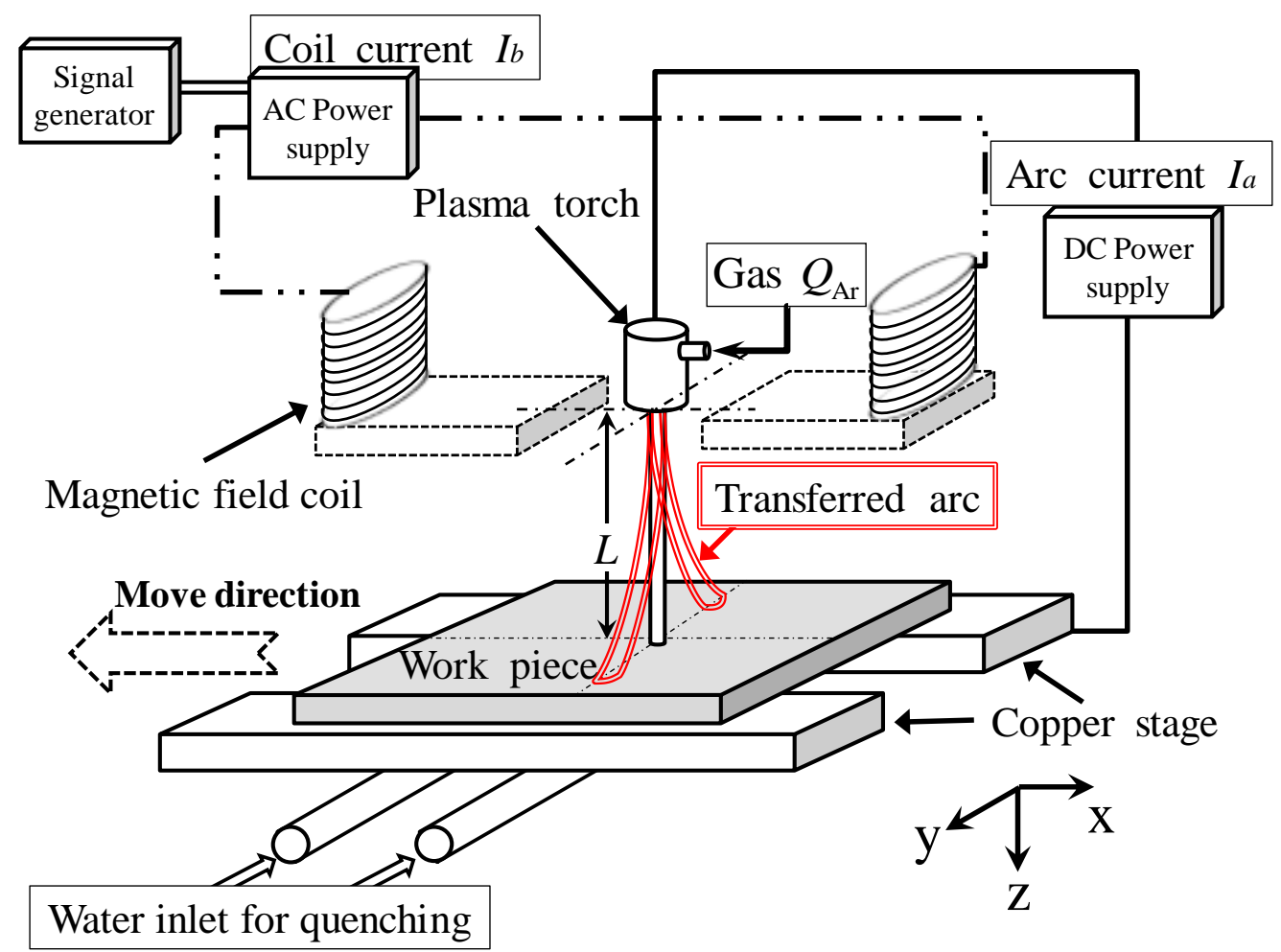

Fig. 3 Schematic arrangement for the heat treatment by magnetically driven arc.

移行型アークは，タングステン電極を持つプラズマトーチと，直流アーク電源が接続された銅製ステージ上に 設置される熱処理対象の鋼材との間に発生する，プラズマトーチにはアルゴンガスが所定の流量で供給され，プ ラズマガスとしてトーチノズルから噴出する. 移行型アークを駆動する交番磁界は交流電源から鉄心の電磁石の 励磁コイルに交流電流が供給され発生する. 励磁用の交流電源は電流波形と周波数をさまざまに変化させること ができる信号発生器と，この信号を増幅する電力増幅器で構成されている．熱処理対象の鋼材を設置するテーブ ルは，陽極となる鋼材に電流を供給するための二本の銅製ステージによる給電機構と，加熱された鋼材を急冷す るための水を鋼材下面に吹き付ける噴射ノズル機構とで構成されている．プラズマトーチを上下方向（z軸方向） に，銅製ステージを水平方向（x 方向）および上下方向（z方向）に移行する駆動システムを備えており，移動方 向，移動距離，移動速度はデジタル制御が可能である. 図 4 に実験で用いられた装置全体の写真を示す。 


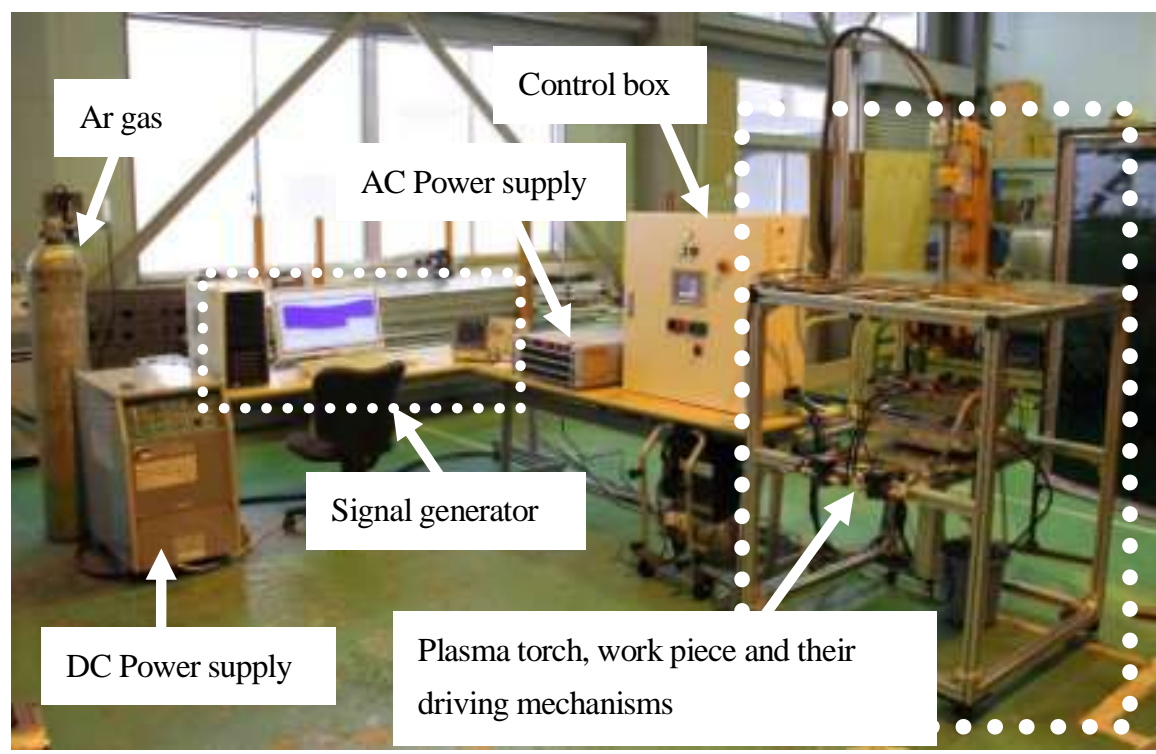

Fig. 4 Developed arrangement of the heat treatment.

\section{$3 \cdot 2$ プラズマトーチおよび直流アーク発生システム}

装置には直流移行型熱プラズマトーチを使用している. 図 5 にプラズマトーチとトーチ駆動部を示す。プラズ マトーチは秋田県立大学とロシア科学アカデミーおよび応用力学研究所（ITAM）が共同設計・製作したもので ある. 陰極はタングステンロッドで，直径 $5[\mathrm{~mm}]$ の穴を持つ水冷されたノズルからプラズマガスが噴出する. プラズマトーチの仕様を表 1 に示寸．プラズマトーチは昇降運動が可能であり，アーク点火時はトーチを鋼材に 近づけて，点火後はトーチを所定の高さまで引き上げて熱処理に移る．プラズマーク発生用の直流電源（株式会 社ダイヘン製，プラズマ切断機「SUPER PLASMA D-12000」）は，出力電流範囲が 30-120 [A]，定格出力電圧は $200[\mathrm{~V}]$ である.

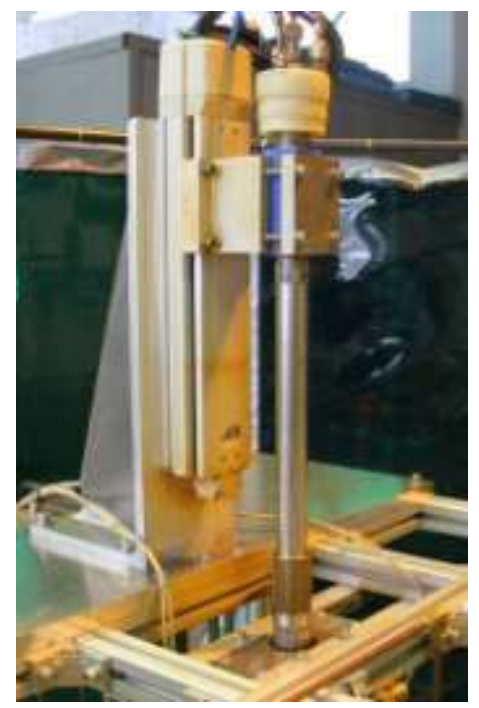

Table 1 Specifications of the plasma torch.

\begin{tabular}{|c|c|}
\hline Maximum arc current & $300[\mathrm{~A}]$ \\
\hline Plasma gas & $\mathrm{Ar}$ \\
\hline Flow rate of the gas & $5-15[\ell / \mathrm{min}]$ \\
\hline Dimension of plasma torch & $\phi 40 \times 600[\mathrm{~mm}]$ \\
\hline
\end{tabular}

Fig. 5 Plasma torch. 


\section{$3 \cdot 3$ 磁界発生システム}

磁界発生システムは励磁電源と鉄心電磁石で構成される．鉄心電磁石に巻かれた励磁コイルに電源より電流が 供給される. 励磁電流の大きさと電流波形を調節することによって, 移行型ア一クの磁気制御が可能となる. そ のため, 磁気駆動アークの発生には外部磁界の制御が重要になる. 励磁電源は任意の周波数と任意の波形を生成 できる信号発生器と, 信号発生器で生成された信号を増幅して励磁電流としてコイルに供給する電力増幅器で構 成される。本装置では信号発生器として任意波形発生機（株式会社エルモス製「AWG-50」）を, 電力増幅器は 松定プレシジョン株式会社製「電力増幅器 POP20-15」を使用した. 信号発生器と電力増幅器を図 6 に示す. 電力 増幅器の出力電流範囲は 0-15 [A]である. 信号発生器によって励磁電流波形を生成することで，磁気駆動ア一ク による加熱幅や加熱分布を自由に制御することが可能になる.

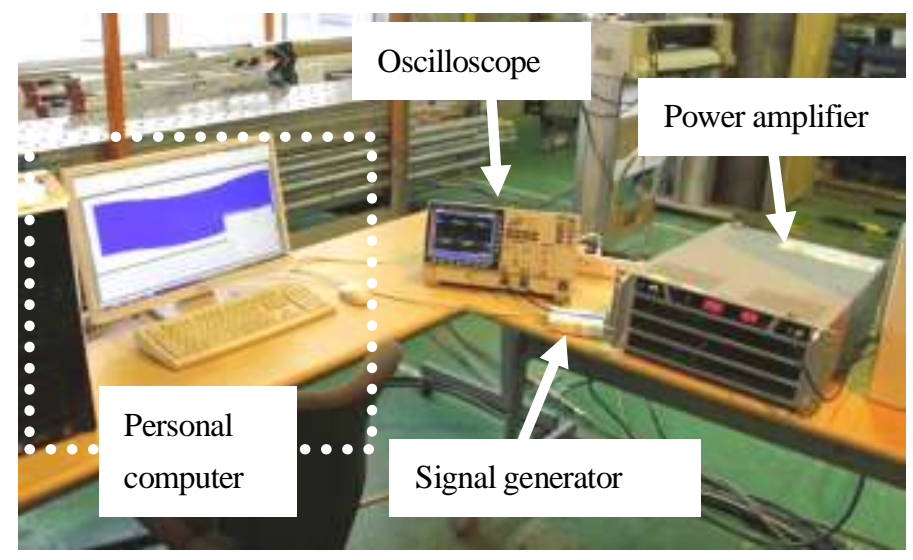

Fig. 6 System to control an electric current for the magnetic field.

図 7 に鉄心電磁石とその寸法を示す．鉄心電磁石は L 字状の鉄心とそれに巻かれる励磁コイルで構成される. 熱処理中 $\mathrm{z}$ 方向では，トーチの端と磁界発生コイルの先端が一致する. 励磁電流と磁束密度の関係を明らかにす るために, 移行型アークが発生する空間の磁束密度を調べた. 磁束密度の測定は, 株式会社東陽テクニカ製「Model 421 Gauss meter」を使用し，プローブを図 8 に示すスケールに合わせて，y, z 方向にそれぞれ 10 [mm] 間隔で計 測した. 図 9 に励磁電流 $I_{\mathrm{b}}=10[\mathrm{~A}]$ の場合の鉄心電磁石から生じる磁束密度分布を示す. トーチ中心を原点とし, 磁束密度は原点で最大で $B=3.7$ [mT] の磁束密度が得られた. $\mathrm{z}$ 方向について, 磁束密度は原点を中心にほぼ対照 的に分布し，原点から離れるに伴い減少する. y 方向に関しては，80 [mm]の鉄心の幅で $B=3.7$ [mT] の均一な磁 束密度が得られた。
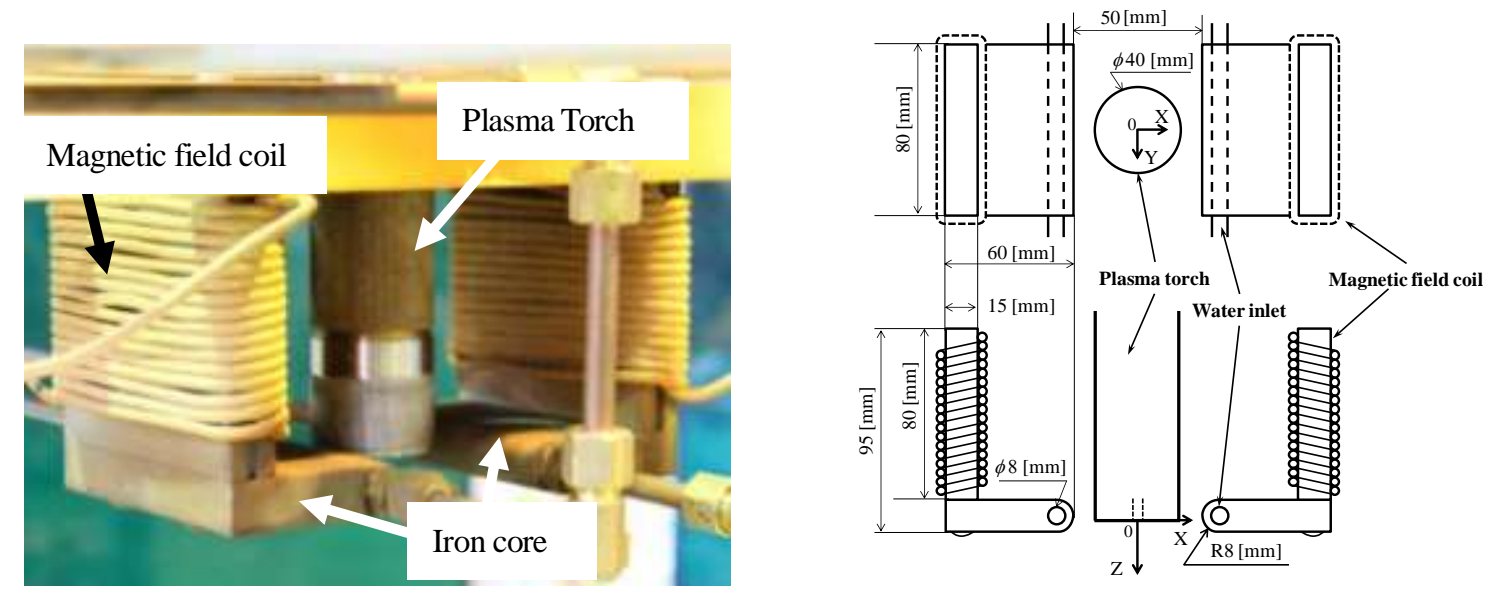

Fig. 7 Electromagnet. 


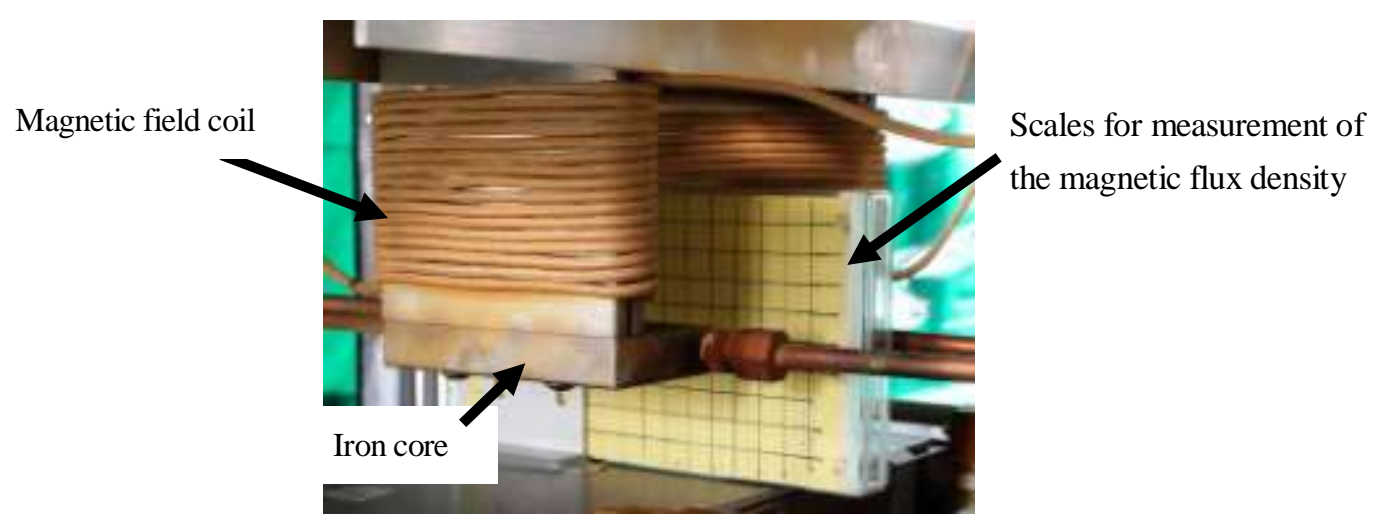

Fig. 8 Scales for mesurement of the magnetic flux density.

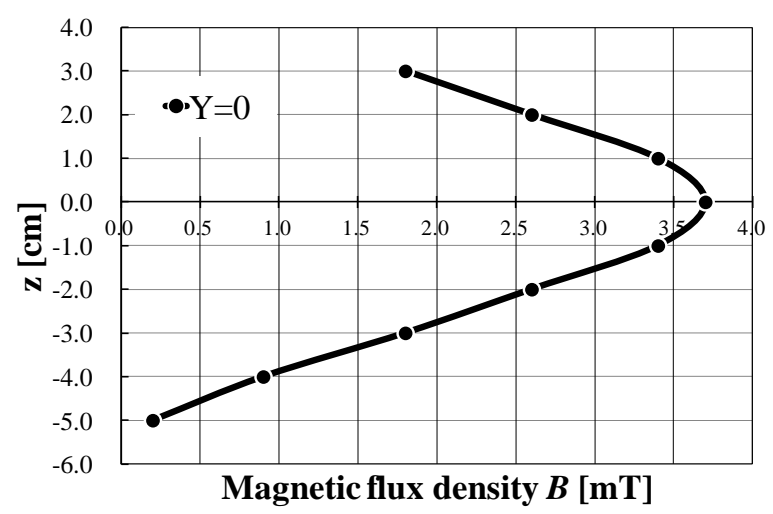

(i) Variation of $\mathrm{B}$ along $\mathrm{z}$ axis.

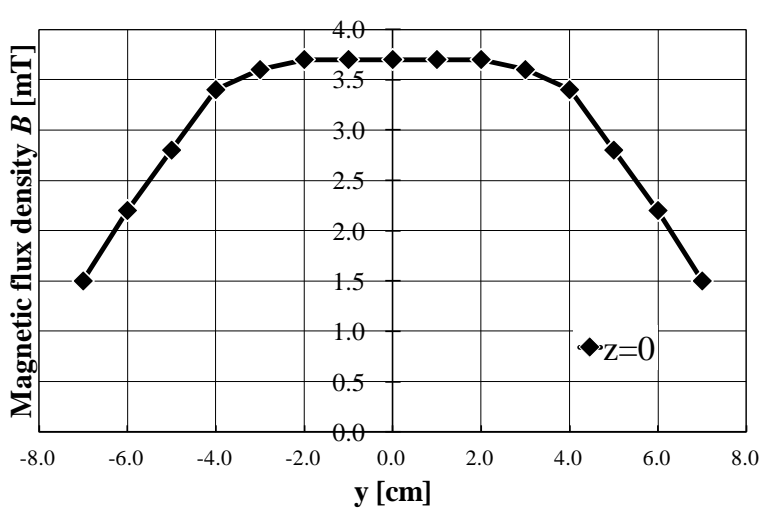

(ii) Variation of B along y axis.

Fig. 9 Distribution of the magnetic flux density at the electric current of 10A.

\section{$3 \cdot 4$ 冷却システム}

鋼材の焼入れ処理には熱処理後の冷却が重要となる．図 10 に示されるように，鋼材が設置される銅製ステー ジはバケット内に取り付けられ，二本の銅製ステージの間から，鋼材の裏に冷却水を吹きつけることができる. 冷却水はバケット内から外部へと排出される. 図 11 に冷却水噴射口と吹付けられる冷却水の様子を示寸. トーチ 直下冷却水 $Q_{1}[\ell / \mathrm{min}]$, 急冷用冷却水 $Q_{2}[\ell / \mathrm{min}]$ の流量は流量計で確認され調節が可能である. $Q_{1}$ は被処理鋼材 の中央部を冷却し，帯状に広範囲を加熱する場合は散水しない. $Q_{2}$ はアークによる加熱位置から鋼材の進行方向 に $50[\mathrm{~mm}]$ 離れた位置に設置されている. すなわち鋼材の送り速度を $v[\mathrm{~mm} / \mathrm{s}]$ とすると，アークによる加熱か ら $50 / v[s]$ 後に冷却が開始される.

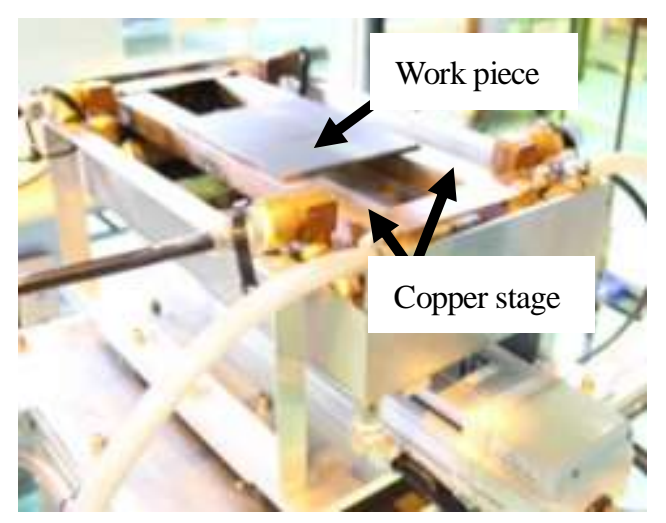

Fig. 10 Anode stage and its travelling mechanisms.
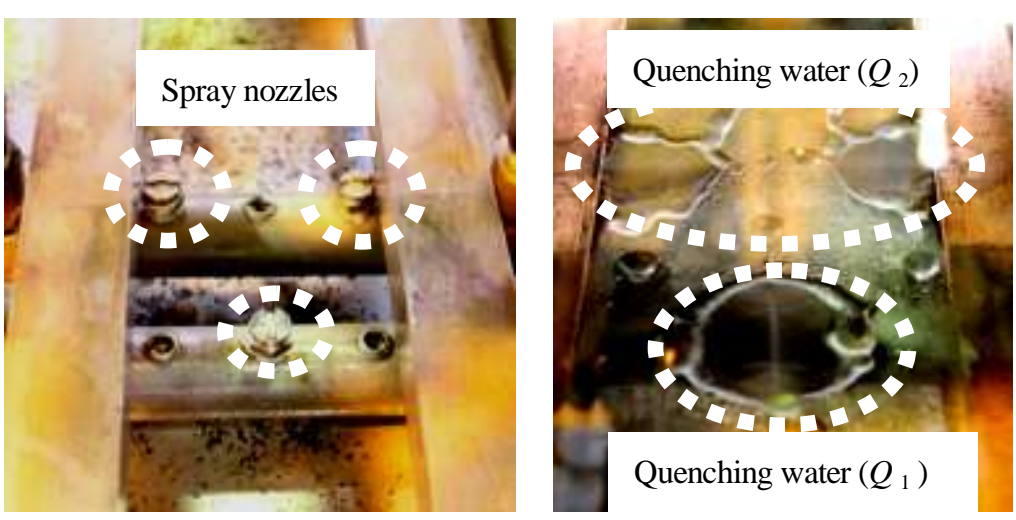

Fig. 11 Quenching by water spray. 


\section{$3 \cdot 5$ 駆動部および制御ボックス}

水冷された銅製ステージには電極がつながれ，ステージ上に置かれた鋼材が陽極として作用寸る．鋼材とプラ ズマトーチの間に移行型アークが発生する．プラズマトーチは昇降運動が可能であり，アーク点火時はトーチを 鋼材表面に近づけ, 点火後にトーチを所定の位置まで引き上げて熱処理を行う.ステージは x 軸方向に稼働でき， 鋼材を移動しながら加熱することができる．鋼材の移動速度は制御ボックスでコントロールすることができ，移 動速度範囲は 0 20 [mm/s] である. また，プラズマトーチと銅製ステージは $\mathrm{z}$ 軸方向の昇降運動が可能で，プラ ズマトーチとの距離を調節寸ることが可能である。プラズマトーチと鋼材との間隔制御は制御ボックスのデジタ ル制御により自動制御される.

制御ボックスは，プラズマトーチおよびステージの昇降運動，鋼材の送り運動，各冷却水の流入，プラズマガ スの流入，励磁電流值，アークの点火・消火が制御できる．さらに，アークの点火から鋼材の泠却までの一連の 熱処理工程をプログラムすることで自動制御が可能である. 図 12 にコントロールボックスを示す.

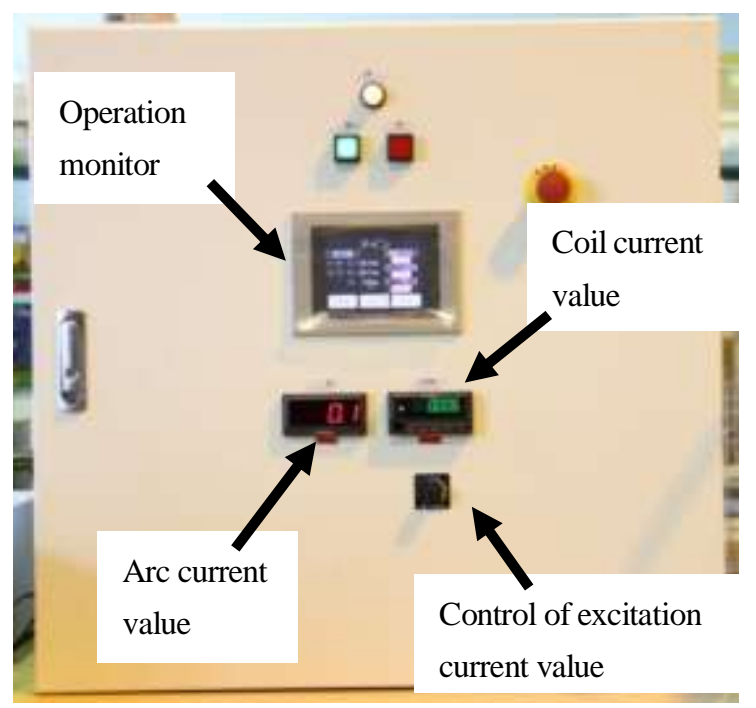

Fig. 12 Control box.

\section{4. 鋼材の熱処理実験}

磁気駆動アークによる鋼材熱処理装置での鋼材焼入れ実験を行った．試験片として実験に用いた鋼材は，厚さ $t=3.2[\mathrm{~mm}]$ の機械構造用炭素鋼鋼材（S45C）である. 実験の狙いは，磁界波形の制御により様々なパターンの 熱処理が可能であることを検証すること，および熱処理により鋼材のビッカース硬さが上昇することを確認する ことである. 熱処理中におけるアークの形状および熱処理後鋼材の表面状態の観察より，磁気駆動アークによる 入熱分布制御が適切に行われていることを確認する．励磁電流の波形によるアークの形状の変化を写真により観 察するとともに，鋼材の熱処理後の表面の変化を観察する．熱処理は大気中で行われるためにアークが照射され た領域の表面は黒い酸化スケールでおおわれる．熱処理後の表面変化の観察は，アーク処理が終了した鋼材表面 をアルミナグリットでブラストし表面の黒皮を除去したのち表面観察する.さらに熱処理後の鋼材断面のビッカ 一ス硬さを測定し，熱処理箇所における焼入れの効果を確認する.

熱処理実験の手順を以下に示す.

（1）各熱処理条件の設定（アーク電流值, プラズマガス流量, 励磁電流波形および電流值, 鋼材とプラズマ トーチ間距離)

(2)アアーク着火位置にプラズマトーチを降下

（3）冷却水供給開始, 励磁電流電通開始

(4) アーク着火

（5）＼cjkstart所定位置までプラズマトーチを上昇後，鋼材移動，熱処理開始 
（6）＼cjkstart所定位置までの鋼材移動が完了したら，プラズマアーク加熱を停止

（7）鋼材が常温になった後，冷却水供給を停止

図 13 に励磁電流波形とそれに対応する熱流束分布の概念図を示す. Type A は鋸歯状波の励磁電流でアークを 駆動した場合で，アークの往復速度は一定であり，鋼材が熱処理される領域は帯状になると予測される．Type B は励磁電流を振幅一定の矩形波とした場合で，アークの往復運動の両端のみに熱が集中し，平行二線状の熱処理 パターンが得られると考えられる．Type C，Type D は Type B における励磁電流值を時間的に変化した波形で， それぞれダイヤモンド形状の二線, 波状の平行二線の熱処理パターンに加熱できると予測される. アーク加熱後 の鋼材表面にはアークで照射された痕跡が残る．照射痕の形状から，どのような励磁電流の印加により，どのよ うなパターンの熱処理が行われたかを確認する.

Wave forms
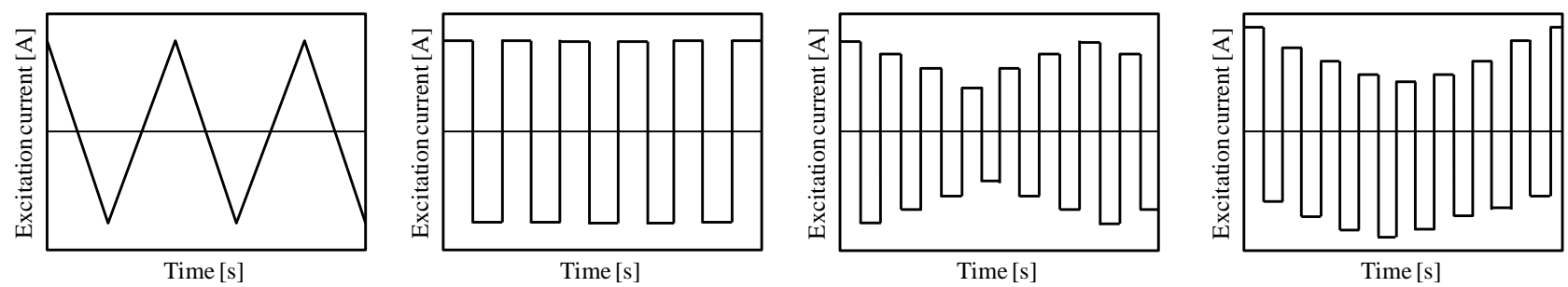

Heating patterns

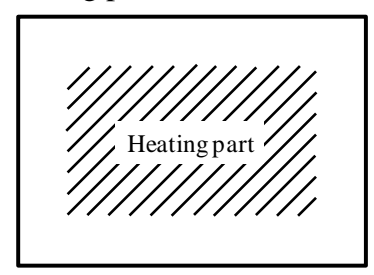

(a) Type A. Belt form.

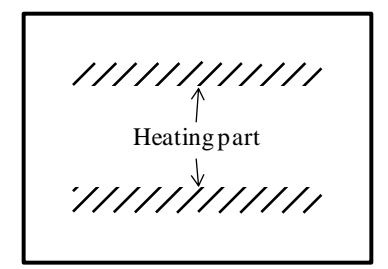

(b) Type B. Parallel straight lines.

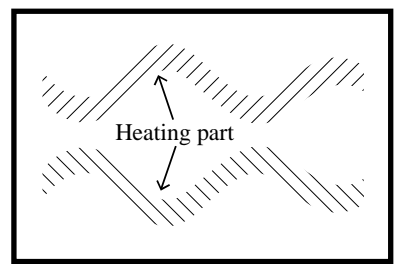

(c) Type C. Two lines in diamond form.

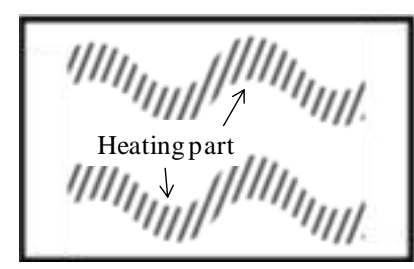

(d) Type D. Parallel wave lines

Fig. 13 Wave forms of coil current and heating patterns.

上記 4 タイプの励磁電流波形に対する実験条件を表 2 にまとめて示す．アークを駆動する交番磁界の励磁電流 周波数はいずれの場合も50[Hz] である.

Table 2 Experimental conditions of various heat treatments.

\begin{tabular}{|c|c|c|c|c|}
\hline Steel $(\mathrm{L} \times \mathrm{W} \times \mathrm{H}[\mathrm{mm}])$ & \multicolumn{3}{|c|}{$\mathrm{S} 45 \mathrm{C} \quad(300 \times 130 \times 3.2)$} \\
\hline Heating pattern & Type A & Type B & Type C & Type D \\
\hline Wave form of coil current & \multicolumn{4}{|c|}{ Refer to Fig. 14.} \\
\hline Flow rate of Ar gas $Q_{\mathrm{Ar}}[\mathrm{kg} / \mathrm{s}]$ & \multicolumn{4}{|c|}{$50 \times 10^{-4}$} \\
\hline Distance between electrodes $L[\mathrm{~mm}]$ & & 80 & 75 \\
\hline Arc current $I_{\mathrm{a}}[\mathrm{A}]$ & 60 & 13.8 & 14.7 & $9.5-12.6$ \\
\hline Coil current $(\mathrm{AC}) \quad I_{\mathrm{b}}[\mathrm{A}]$ & 1.5 & 1.2 & 1.0 \\
\hline Travelling speed of work piece $v[\mathrm{~mm} / \mathrm{s}]$ & 0 & \multicolumn{3}{|c|}{0.3} \\
\hline Flow rate of quenching water $Q_{1}[\ell / \mathrm{min}]$ & 0.6 \\
\hline Flow rate of quenching water $Q_{2}[\ell / \mathrm{min}]$ & \multicolumn{4}{|c|}{} \\
\hline
\end{tabular}

励磁電流波形に応じて入熱分布が変化し, 励磁電流值は加熱幅を決定する.鋼材の送り速度およびアーク電流, 冷却水水量は鋼材への入熱量を考慮して決定した. 冷却水 $Q_{1}$ の噴射位置はトーチ直下であり, 鋼材裏面の中央部 を泠却するために設置されている. 冷却水 $Q_{2}$ はトーチ直下から鋼材の進行方向に離れて端部二箇所を泠却するよ 
う設置されており，鋼材がアーク照射により加熱された後，所定の時間経過後に水冷が開始されるように散水位 置が決められている.

熱処理された鋼材表面を観察した後，鋼材を切断し，断面のビッカース硬さ分布を測定し焼入れの効果を調査 した. ビッカース硬さ分布は微小硬度計（株式会社アカシ「HM124 VALPAK2000」）により，鋼材の幅方向およ び厚さ方向について測定した。ビッカース硬さ試験の試験力は $1[\mathrm{~N}]$ とした.

\section{5. 実験結果}

\section{$5 \cdot 1$ 熱処理パターン}

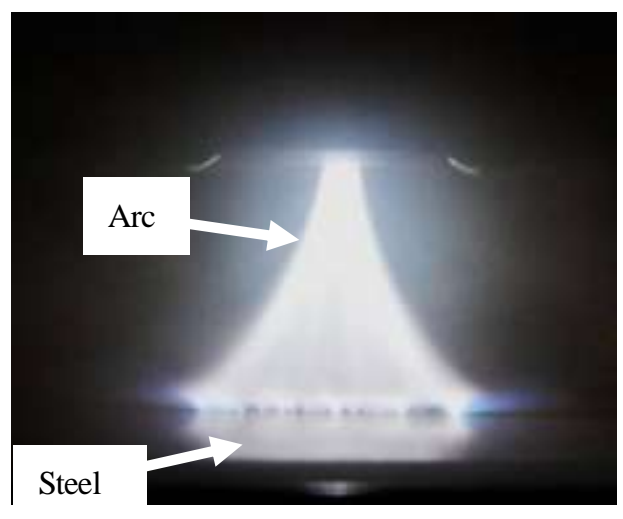

(a) Type A

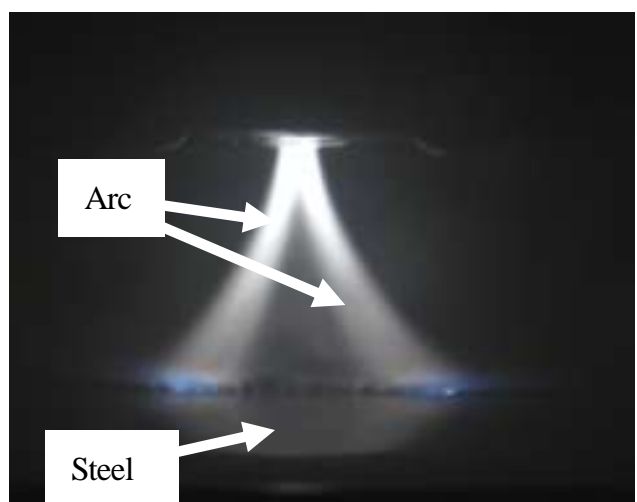

(b) Type B, C, D

Fig. 14 Arcs in different wave forms.

熱処理中のアーク形状を図 14 (a) に示寸. 励磁電流波形 Type A の場合, 予想された通りの広幅化したアーク が得られることが確認された．励磁電流波形 Type B，Type C およびType D の場合は，図 14（b）に示されるよ うに, 広がった両端にアークが集中し，二箇所に分かれたアークによる局所加熱が可能であることが確認された.

図 15 （a）に励磁電流波形が Type A の場合の，熱処理後の鋼材表面状態と対応寸る励磁電流波形を示寸．励磁 電流の波形に単純な三角波を適用すると，鋼材幅方向の熱流束分布は均一になるが，振幅の両端で熱損失が増え るため鋼材幅方向の温度分布が均一にならず中央で高く端部に向かい温度が低下していく分布になると考えられ る.この端部での温度低下を防止するため, 実際に採用した Type A の波形は三角波の上下の一部を切り取り平ら にし，両端の入熱量を増やしている．このとき，励磁電流 $I_{\mathrm{b}}=13.8[\mathrm{~A}]$ で $50[\mathrm{~mm}]$ の幅の照射痕が得られ，帯状 に均一な熱処理が行われており，磁気駆動をせねば得られない広幅の熱処理がなされていることが確認できた。

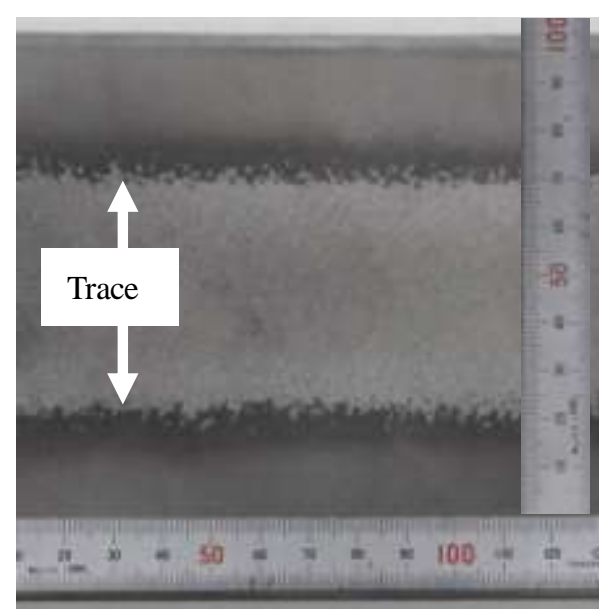

Trace of the arc heating on the steel serface.

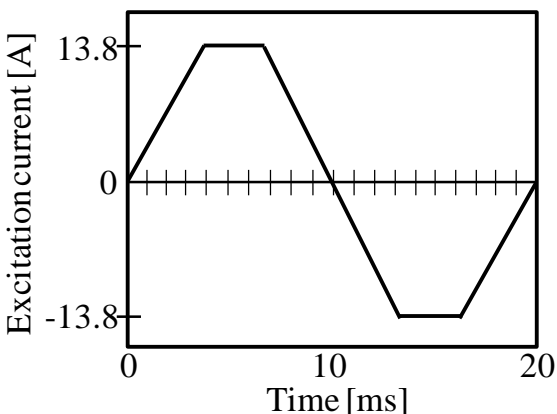

Wave form.

(a) Type A 


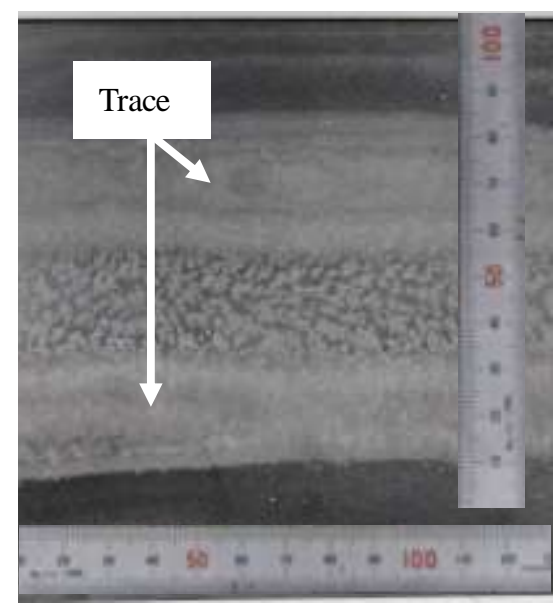

Trace of the arc heating on the steel serface.

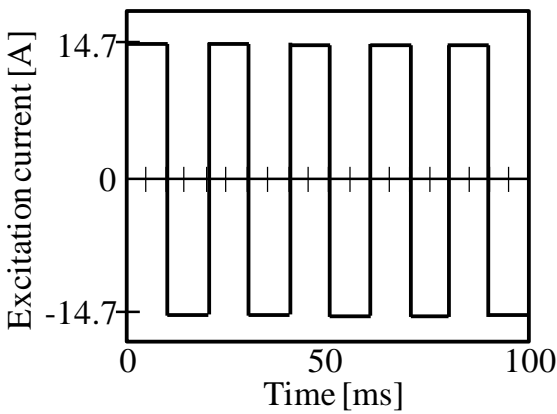

Wave form.

(b) Type B

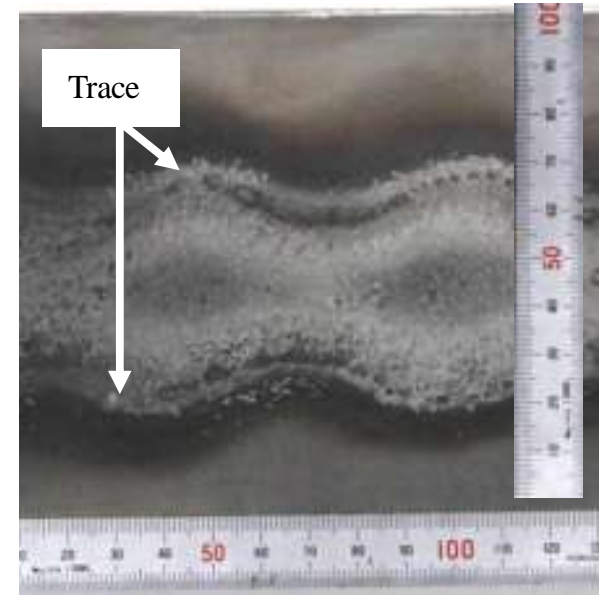

Trace of the arc heating on the steel serface.

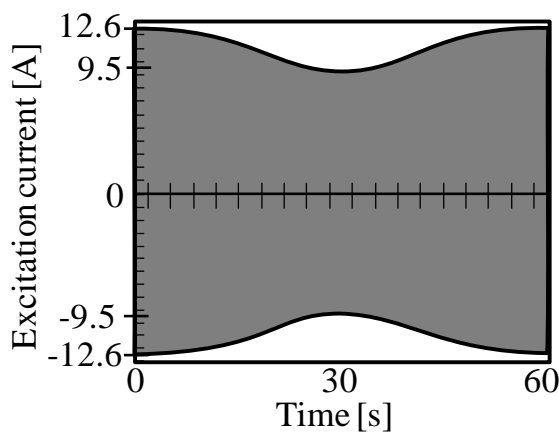

Wave form.

(c) Type C

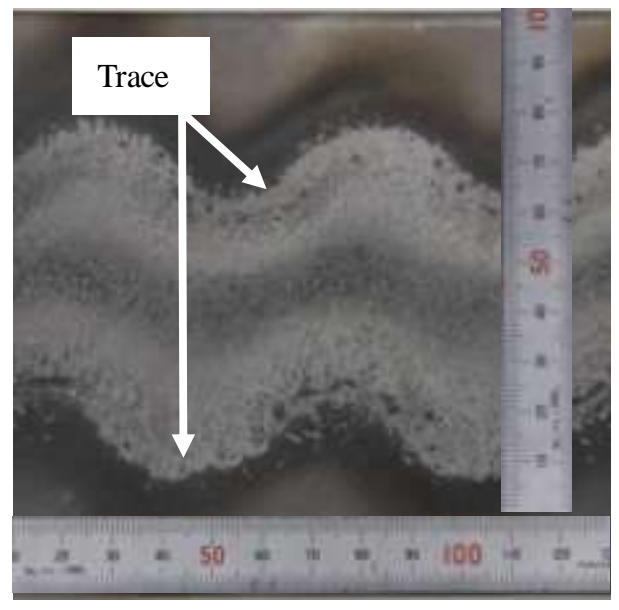

Trace of the arc heating on the steel serface.

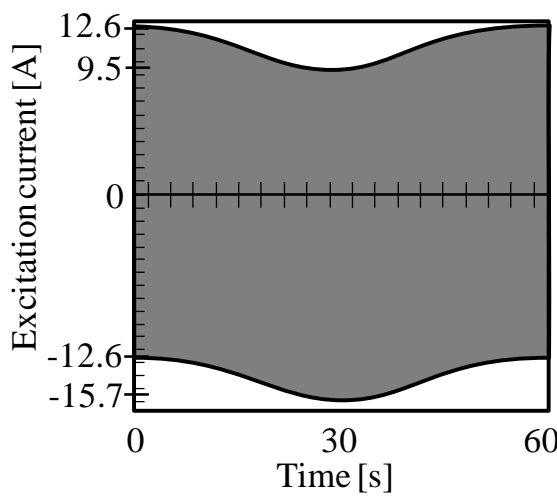

Wave form.

(d) Type D

Fig. 15 Traces of arc heating obtained by various wave forms of coil current.

図 15 (b)，(c)，（d）において，Type B は 50 [Hz] の周波数の矩形波であるが，Type C，Type D は Type B に示 寸矩形波に周期 60 [sec] のゆっくりとした変調をかけたものであり, 励磁電流波形の時間軸の単位は Type A, Type 
B では [ms] であるのに対し，Type C, Type D の時間軸単位は [s] で示している. このとき，二本のライン状で 熱処理が行われており，励磁電流值と電流波形の制御により，狙った場所に狙った形状で熱処理ができることが 確認された．さらに，すべての実験条件で鋼材表面の凹凸が少なく，良好な表面状態が得られた.

\section{$5 \cdot 2$ 熱処理後のビッカース硬さ分布}

熱処理後の鋼材を切断し，断面のビッカース硬さを測定することで，焼入れの効果を確認した．ビッカース硬 さ測定は鋼材の送り方向と直交する断面に対して行った. 熱処理前の S45C のビッカース硬さは HV 200 程度で ある ${ }^{(8)}$. 図 16 に励磁電流波形 Type B の場合の熱処理後鋼材の断面図, 図 17 に鋼材断面のビッカース硬さ分布を 示す．ビッカース硬さ測定における原点は，プラズマトーチのノズル直下の鋼材表面とし，鋼材の表面から厚さ 方向に 0.5 および $2.7[\mathrm{~mm}]$ について測定された. 測定の結果, 熱処理によるビッカース硬さ変化は鋼材の厚さ方 向は表面から裏面まで均一に得られ，ビッカース硬さは約 3 倍になることが確認された. 図 17 は Type B の結果 のみを示しているが，同椂のビッカース硬さの上昇が他のタイプでも起こることを確認している.

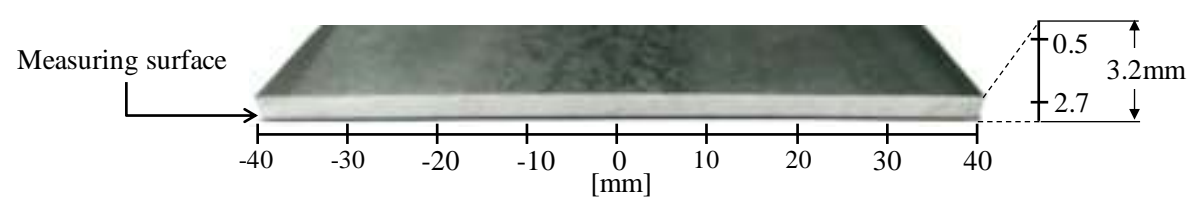

Fig. 16 Cross section of steel when the wave form of coil current is Type B.

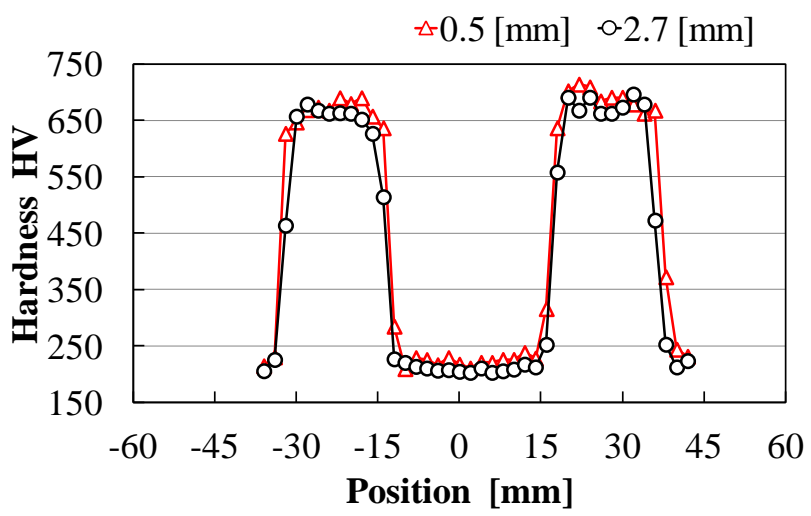

Fig. 17 Vickers hardness distribution when the wave form of coil current is Type B.

\section{6. 討論}

熱処理には, 要求される範囲の硬さが得られるだけでなく, 表面溶融がなく綺麗な表面状態であること, 処理時間が短いこと，消費エネルギー量が小さいことが求められる. 本技術における熱処理は，鋼材表面か ら入熱して鋼材深さ方向に熱を伝導させて鋼材の温度を上昇させる方法をとっている.このため鋼材表面と

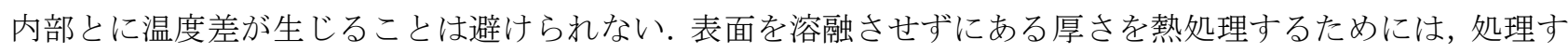
べき鋼材の厚さとアーク出力と鋼材の移動速度とはどのような関係を満たすべきかについて定量的に検討 する.

議論を単純化するために，ある熱流束密度 $q_{0}\left[\mathrm{~W} / \mathrm{m}^{2}\right]$ の熱が時刻 $\tau=0[\mathrm{~s}]$ で鋼材表面に投入され始め，熱 が一次元的に鋼材の深さ方向に伝導寸るモデルを考える. 鋼材の厚さを無限長として, $\tau[\mathrm{s}]$ 時間後の深さ $z$ [m] の位置での温度 $T-T_{0}[\mathrm{~K}]$ について考える.

一次元熱伝導の式は式（3）で与えられ，

$$
\frac{\partial T}{\partial \tau}=\alpha \frac{\partial^{2} T}{\partial z^{2}}
$$


$\tau[\mathrm{s}]$ 時間後の深さ $z[\mathrm{~m}]$ の位置の温度 $T-T_{0}[\mathrm{~K}]$ は式（4）となる.

$$
T(z, \tau)-T_{0}=\frac{q_{0}}{k}\left\{\sqrt{\frac{4 \alpha \tau}{\pi}} \exp \left(-\frac{z^{2}}{4 \alpha \tau}\right)-z\left(1-\operatorname{erf} \frac{z}{\sqrt{4 \alpha \tau}}\right)\right\}
$$

ここで $T_{0}$ は鋼材の初期温度であり常温とする. $k[\mathrm{~W} /(\mathrm{m} ・ \mathrm{~K})]$ は試料の熱伝導率であり, 試料の密度を $\rho\left[\mathrm{kg} / \mathrm{m}^{3}\right]$, 比熱容量 $c[\mathrm{~J} /(\mathrm{kg} \cdot \mathrm{K})]$ とすれば，熱拡散係数 $\alpha\left[\mathrm{m}^{2} / \mathrm{s}\right]$ は式（5）で表される.

$$
\alpha=\frac{k}{\rho c}
$$

二つの異なる熱流束密度の条件で, 式（4）の数值計算を行い，各深さでの温度の時間変化を図18に示した. 表 3に計算に用いた数值をまとめて示す．物性值として純鉄873.15 [K] での值を代表值として用いている. 図18（a） は $q_{0}=4.0 \times 10^{6}\left[\mathrm{~W} / \mathrm{m}^{2}\right]$ の場合, 図 18 (b) は $q_{0}=12.0 \times 10^{6}\left[\mathrm{~W} / \mathrm{m}^{2}\right]$ の場合の温度変化である. 熱流束密度が大きく なると表面と内部との温度差が大きくなることがわかる. S45C 鋼材の焼入れに必要な最低加熱温度である 1100 $[\mathrm{K}]$ を熱処理限界温度として考え, $z=3[\mathrm{~mm}]$ の深さまで焼入れするための時間 $\tau[\mathrm{s}]$ を図 18 より求めると, $q_{0}=$ $12.0 \times 10^{6}\left[\mathrm{~W} / \mathrm{m}^{2}\right]$ では $\tau=4.0[\mathrm{~s}]$ となる.一方, 熱流束密度が $1 / 3$ の $q_{0}=4.0 \times 10^{6}\left[\mathrm{~W} / \mathrm{m}^{2}\right]$ では $\tau=18.0[\mathrm{~s}]$ となり, 処理時間は 4.5 倍になっている. 単位面積当たりの消費エネルギー量は時間 $\tau$ と熱流束密度 $q_{0}$ の積で与えられ るので, $q_{0}=12.0 \times 10^{6}\left[\mathrm{~W} / \mathrm{m}^{2}\right]$ の場合の消費エネルギー量は, $q_{0}=4.0 \times 10^{6}\left[\mathrm{~W} / \mathrm{m}^{2}\right]$ の場合よりおよそ $30 \%$ 削減で きる．熱流束密度が大きいほど短時間処理が可能で，省エネルギーとなることがわかる．

しかし, 加熱後の表面状態を考慮すると, $z=0[\mathrm{~m}]$ の位置において, 図 18 (a) の場合は $\tau=18.0[\mathrm{~s}]$ で $T=1400$ $[\mathrm{K}]$ であり表面は溶融しないが，図 18 (b) の場合は $\tau=4.0[\mathrm{~s}]$ で $T=1900[\mathrm{~K}]$ であり，溶融温度の $1800[\mathrm{~K}]$ を 超えており，表面溶融が発生する．熱流束密度が大きいほど表面溶融しやすいことがわかる.

以上の考察より，板厚 $3[\mathrm{~mm}]$ の鋼材を熱処理する適切な条件は，図 18 （a）と（b）の場合の間に存在すると 考えられる.

Table 3 Computational condition.

\begin{tabular}{|rr|c|}
\hline Thermal conductivity & $k[\mathrm{~W} /(\mathrm{K} \cdot \mathrm{m})]$ & 38.9 \\
\hline Density of sample & $\rho\left[\mathrm{kg} / \mathrm{m}^{3}\right]$ & $7.87 \times 10^{3}$ \\
\hline Specific heat capacity & $c[\mathrm{~J} /(\mathrm{kg} \cdot \mathrm{K})]$ & 699 \\
\hline Thermal diffusion coefficient $\alpha\left[\mathrm{m}^{2} / \mathrm{s}\right]$ & $7.07 \times 10^{-6}$ \\
\hline Heat flux density & $q_{0}\left[\mathrm{~W} / \mathrm{m}^{2}\right]$ & $12.0 \times 10^{6}$ \\
& $4.0 \times 10^{6}$ \\
\hline
\end{tabular}

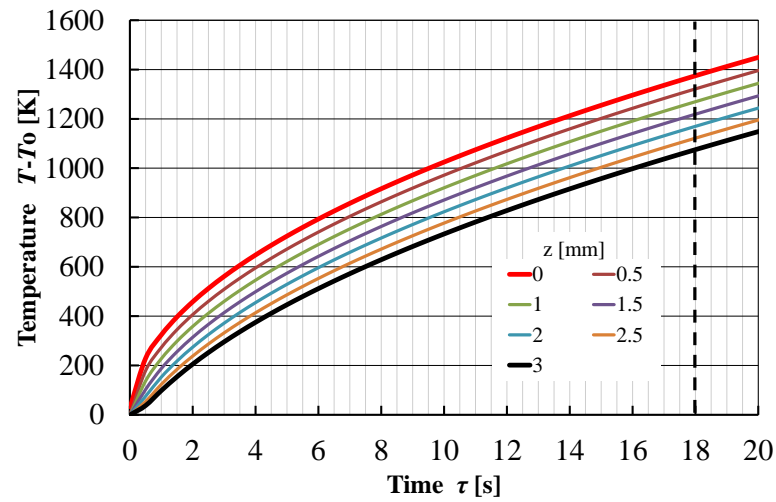

(a) $q_{0}=4.0 \times 10^{6}\left[\mathrm{~W} / \mathrm{m}^{2}\right]$

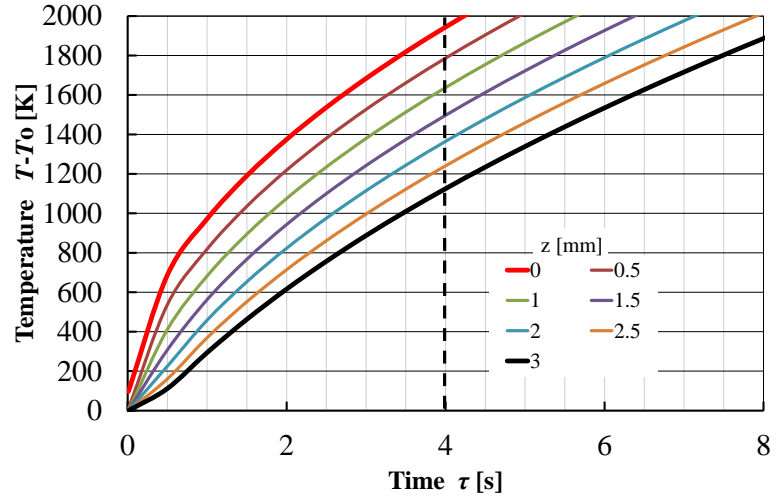

(b) $q_{0}=12.0 \times 10^{6}\left[\mathrm{~W} / \mathrm{m}^{2}\right]$

Fig. 18 Temperature variations with time for various depth. 
この一次元熱伝導モデルを，速度 $v[\mathrm{~m} / \mathrm{s}]$ で移動する鋼材を広幅化した磁気駆動アークで加熱しながら熱処理 を行う図19の現実モデルに対応させて考えてみると，熱源であるアークの加熱面での直径 $d_{0}[\mathrm{~m}]$ とし，鋼材が熱 源に対して速度 $v[\mathrm{~m} / \mathrm{s}]$ で動いているとき, 鋼材表面上のある一点 $\mathrm{A}(x, y)$ での加熱時間 $\tau[\mathrm{s}]$ は式（6）で見積も ることができる。

$$
\tau=\frac{d_{0}}{v}
$$

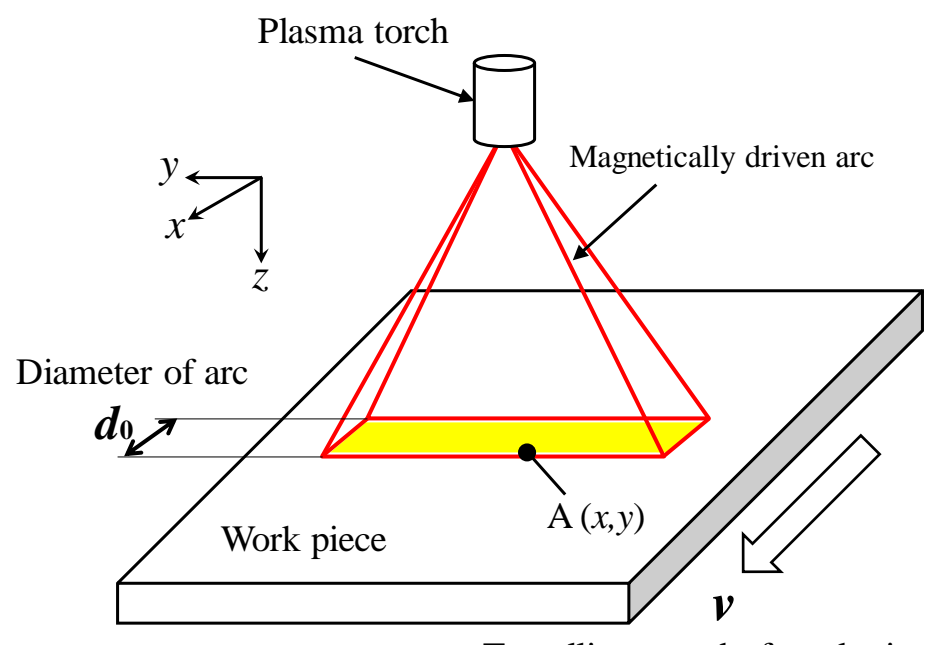

Travelling speed of work piece

Fig. 19 Schematic illustration of relation between travelling speed $v$ and heating time $\tau$.

式（6）より，定量的に求められた加熱時間 $\tau[\mathrm{s}]$ と，実験的に見積もられたアークの加熱面での直径 $d_{0}[\mathrm{~m}]$ か ら，鋼材の送り速度 $v[\mathrm{~m} / \mathrm{s}]$ を推定することができる. アーク出力と温度変化の関係は，プラズマトーチの性能 やアークによる加熱面積，鋼材の材質・厚さにより異なるため，鋼材の送り速度を推定するには，それらを考慮 する必要がある。

\section{7. 結言}

磁気駆動アークを用いた新規な熱処理装置の開発を行った．磁気駆動アークは直流移行型アークにこれと直交 する交番磁界を印加し，アークの往復運動により広幅化したアークである. 磁気駆動アークは磁界の強度を調節 することによりアークの往復運動の振幅を容易に変えることができ，さらに交番磁界の変動波形を変化させるこ とにより熱源内のエネルギー分布を制御することができる，磁気駆動アークを用いた鋼材熱処理装置は，直流ア 一ク発生機構，交番磁界発生機構，試料およびトーチの移動機構，加熱試料の冷却機構で構成される.

この装置を用い S45C 鋼材を処理材料として熱処理を行った結果を以下に示す.

（1）磁気駆動アークの制御により様々なパターンの加熱が可能である.

（2）一本のアークトーチで，様々な間隔で二箇所を同時に加熱することが可能である.

（3）熱処理後の S45C 鋼材のビッカース硬さは処理前に比較して約 3 倍に増加した.

（4）任意の形状パターンの熱処理が可能であり, 装置の有用性を確認した.

（5）アーク出力と鋼材の送り速度については，プラズマトーチの性能，アークによる加熱面積および熱処理さ れる鋼材の材質・厚さを考慮して推定する必要がある.

本研究は, 秋田県重点分野研究開発プロジェクト事業の支援を受け行われた. 


\section{文献}

(1) Arata, Y., and Maruo, H., "Magnetic Control of Arc Plasma and Its Application for Welding", Technology Reports of the Osaka University, Vol. 22, (1972), p. 135.

(2) Harry, J.E., and Goodwin, D., "Surface Heat Treatment Using a Plasma Torch with a Magnetically Traversed Arc", Proceedings of the 4th International Conference on Advances in Welding Processes, Vol. 181, (1978).

(3) Solonenko, O.P., and Fedorchenko, A.I., Plasma Jets in the Development of New Materials Technology (1990), pp. 485- 492. CRC Press.

(4) Takeda, K., "Generation of Magnetically Oscillating Plasma Arc and Its Properties", Journal of High Temperature Society, Vol. 16, No. 6 (1990), p. 357.

(5) Toh, T., Tanaka, J., Maruki, Y., Yamamoto, T., and Takeda, K., "Magneto Hydrodynamic Simulation of DC Arc Plasma under AC Magnetic Field", ISIJ International, Vol. 45, No. 7 (2005), pp. 947-953.

(6) Tanaka, M., Terasaki, H., Narita, R., Kobayashi, K., Fujii, H., and Ushio, M., "Anode Heat Transfer in TIG Arc and Its Effect on Weld Penetration”, Quarterly Journal of the Japan Welding Society, Vol. 23, No. 3 (2005), pp. 398-404.

(7) Yamamoto, T., Takeda, K., Toh, T., and Tanaka, J., "Distribution of Heat Flux Transported by a Magnetically Driven Arc," Thin Solid Films, Vol. 515, No. 9 (2007), pp. 4228-4233.

（8）田中政夫，朝倉健二，機械材料，第 2 版 (2008), p. 160, 共立出版株式会社.

(9) Matsumoto, N., Usami, T., Kuno, I., Yamamoto, T., Sugimoto, M., Kumagai, S., and Takeda, K., "Heat Flux of a Transferred Arc Driven by a Transverse Magnetic Field", Advances in Materials Science and Engineering, Vol. 2009, (2009), DOI: $10.1155 / 209 / 782048$.

(10) Yamamoto, T., Matsumoto, N., Sugimoto, M., Sudo, S., Toh, T., and Takeda, K., "Theoretical Consideration of Heat Flux Distribution of Arc Driven by AC Magnetic Field”, ISIJ International, Vol. 49, No. 12 (2009), pp. 1845-1849.

(11) Matsumoto, N., Yamamoto, T., Sugimoto, M., Kumagai, S., and Takeda, K., "Heat Flux Distribution of DC Arc under AC Magnetic Field", International Journal of the Society of Materials Engineering for Resources, Vol. 17, No. 2 (2010), pp.136-140. 